\title{
CURRENT PROBLEMS IN THE USE OF KEY-EXECUTIVE STOCK OPTION PLANS
}

\section{By Abraham I. GordoN*}

An incentive given key-executive personnel to come to or remain with the corporation frequently takes the form of some means of acquiring a corporate ownership-interest, very often a stock option plan. The typical stock option plan provides that the keyexecutive may buy on or before some future date the corporate stock spccifically set aside for this purpose. While the ostensible purpose of such plans is to encourage the key-executive to endeavor to raise the value of his option, and consequently the value of the holdings of the shareholders, today there is the additional taxsaving inducement.

The use of stock option plans has gained impetus under the Revenue Act of $1950,{ }^{1}$ which has made such plans increasingly attractive to both corporate management and the key-executive ${ }^{2}$ recipients. While this comment is concerned primarily with the problems raised by that Act and the Defense Production Act of $1950,{ }^{3}$ a brief summary of the classical problems besetting stock option plans is here discussed, if only because recent decisions reemphasize that these problems still face the corporation attorney.

The Problem of Premptive Rights. ${ }^{4}$ Depending upon the jurisdiction, the pre-emptive right of the stockholder to be offered his pro rata share in the issuance of corporate stock may ${ }^{5}$ or may

* Second year law student, Duke University; B.A. University of Bridgeport, 1951.

126 U. S. C. $\$ 130$ A.

2 Although stock options are usually called employee stock options, the appellation key-executive is used here, since a review of the cases shows that it is key-executives who are the principal beneficiaries of such plans. Lesser employees nsually are offered opportunities to buy stock under plans requiring a more definite commitment.

${ }^{3} 50$ U. S. C. APP. $\$ 2061$ et seq.

- See generally Drinker, The Preemptive Right of Shareholders to Subscribe to New Shares, 43 HARv. L. REv. 586 (1930); Morawitz, The Preemptive Right of Shareholdars, 42 HABV. L. REV. 186 (1928); 11 FLETCHER, CYCLOPEDIA OF THE LaW of Private Corporations (Perm. ed.), \$5135 et seq.; anno. 138 A.I.R. 526 (1941).

c Hammer v. Werner, 239 App. Div. 38, 265 N. Y. Supp. 172 (2d Dep't 1933). Cf. Dunlay v. Avenue M Garage \& Rep. Co., 253 N. Y. 274, 170 N.E. 917 (1930); Runswick v. Floor,-Utah-, 208 P.2d 948 (1949). 
not $^{6}$ be limited to shares issued upon an increase, by appropriate charter amendment, in the originally authorized number of shares. Therefore, in many states it would be advisable, wherever possible, that the stock used in the option plan come from either treasury stock or stock originally authorized but unissued, if only to get the benefit of statements in judicial opinions that pre-emptive rights do not extend to such stock. ${ }^{7}$

The careful attorney may well decide not to risk the pre-emptive right assertion and include in the articles of incorporation an appropriate provision which will deny such right. While such a provision inserted in the original articles is usually valid even without an express statutory authorization, state statutes may expressly permit such a clause. ${ }^{8}$ If no such provision is made in the original articles, it still may be possible to make a valid amendment of the articles under the state charter-amendment statute. While some such amendment statutes specifically permit the elimination of pre-emptive rights, ${ }^{9}$ there may still be the problem of the preemption right claimant who owned his stock prior to the enactment of the statute. ${ }^{10}$ An occasional statute specifically faces the stock option situation by denying the pre-emptive rights if the plan is approved by the stockholders. ${ }^{11}$ The statutes which permit the elimination of the pre-emptive rights usually provide that if a

- Ames v. Mengel Co., 190 F.2d 344 (2d Cir. 1951); Snelling v. Bichard, 166 Fed. 635 (C.C.S.D.N.X. 1909); Crosby . Stratton, 17 Colo. App. 212, 68 Pac. 130 (1902); Yasik v. Wachtel, 25 Del. Ch. 247, 17 A.2d 309 (1941); Hall จ. McLuckey, 134 W. Va. 595, 60 S.E.2d 280 (1950).

: "It seems to be a majority rule that existing stockholders have no right to a preference where the corporation reacquires shares of its stock once is. sued, and reissues them, and that such shares are assets of the corporation, and may be disposed of by it either to stockholders or to strangers, as it may deem best." FLETCHER, op. cit. supra note 4 , $\$ 5160$. "It is generally said that the preemptive privilege does not apply to the balance of the originally authorized shares." WASHINGTON AND ROTHCHID, COACPENSATING THB CORPORATE EXECUTIVE (REV.Ed. 1951), p. 105.

${ }^{8}$ Demering's Calif. Code ann., Corporations \& 1106.

- Cons. GEN. Stats. (1949). 5219 (vote of $\frac{2 / 3}{3}$ of each class); IDaHo Code ANN., $\$ 30-120$ (7) (vote of majority of outstanding stock); JoNES' ILL. STAT. ANN., 32.024 (vote of " $\% / 3$ of shares entitled to vote") ; BURNB' IND. BTAT. ANN., 25.223 (c) (vote of " $80 \%$ of the shares of each class of stock"); COMrP. LATWS MICH. (1948), $\$ 450.31$ ( $\%$ of each class of shares entitled to the preemptive rights); PAGE's OHIO GEN. CODE ANN., $8623-35$ (d) (\% of the shares entitled to such preemptive rights).

${ }^{20}$ Albrecht, Maguire \& Co., Inc. v. General Plastics, Inc., 256 App. Div. 134, 9 N.Y.S.2d 415 (4th Dep't 1939); aff'd without opinion 280 N.Y. 840, 21 , N.E.2d 887 (1939). See also N. Y. STOCK CoRP. LAT, \$14.

11 Page's Ohro Gen. Code ANN., \$8623-35. 
majority, ${ }^{12}$ or perhaps two-thirds, ${ }^{13}$ of the outstanding stock approves of the elimination of the rights, the stock to be used may be issued without concern for these prior pre-emptive rights. However, in a few states, those dissenting from the elimination may elect to have their stock purchased by the corporation at its fair market value. ${ }^{14}$

The Problem of Consideration..$^{15}$ It has frequently been said that unless the corporation receives adequate consideration for the stock option, the issuance of stock under it may be void as a gift or as a waste of the corporate assets and, as such, illegal. ${ }^{\text {is }}$

"Sufficient consideration to the corporation may be, inter alia, the retention of the services of an employee, or the gaining of the services of a new employee, provided there is a reasonable relationship between the value of the services to be rendered by the employee and the value of the options granted as an inducement or compensation."

While a recent case ${ }^{18}$ said that inducement was not specifically required, in the cases in which stock options were litigated it appeared that the consideration received by the corporation was either the retention of the services of a present employee or the acquisition of the services of a new employee. In each of the cases

${ }^{12}$ N. Y. Stock CoRp. LaW, $\$ 14$. Cf. Colo. STAt. ANN., c.41, $\$ 42$.

20 Defring's CalifF. Code ANn., Corps., 1107-1108. Cf. Idaho Code ANN., 29-119; PAGE's OHIO GEN. CODE, \$S 8623-20(a), 8623-35, 8623-36; Ofua Bus. Corp. Act, 45-47; Pubdon's PenN. Stat. ANN., Bus. Corp. LAW, 612 .

24 N. Y. STOCK CoRP. LAW, 14.

${ }^{15}$ See generally Note, The Legality of Stock Option Grants to Corporate Officers, 49 CoL. I. REv. 232 (1949); Comment, Stock Option Incentive Employment Contracts for Corporation Executives, 47 MICH. L. REv. 1179 (1949); reference may be made to Fordham, Some Legal Aspects of Employee Stock Purchase Plans, 8 N. C. L. REv. 161 (1929).

${ }^{10}$ McQuillen v. National Cash Register Co., 27 F.Supp. 639 (Md. 1939), aff' $d$ 112 F.2d 877 (4th Cir. 1940), cert denied 311 U. S. 695 (1940); Holthusen v. Edward G. Budd Mfg. Co., 52 F.Supp. 125 (G.D.Pa. 1943), reversed 53 F.Supp. 488 (E.D.Pa. 1943); Wyles v. Campbell, 77 F.Supp. 343 (Del. 1948); Wise v. Universal Corp., 93 F.Supp. 393 (Del 1950); Rosenthal v. Burry Biscuit Corp., 30 Del. Ch. 299, 60 A.2d 106 (1948); Sandler v. Shenley Industries, Inc., -Del. Ch.-, 79 A.2d 606 (1951); Abrams v. Allen, 36 N.Y.S.2d 174 (1942), aff'd without opinion 266 App. Div. 835, 42 N.Y.S.2d 641 (1st Dep't 1943), motion for leave to appeal or for reargument denied 266 App. Div. 948, 44 N.Y.S.2d 337 (1st Dep't 1943).

${ }^{27}$ Kerbs v. California Eastern Airways, Inc., -Del.-, 90 A.2a 652, 656 (1952), reversing -Del. Ch.-, 83 A.2d 473 (1951), reargument denied -Del. -, 91 A.2d 62 (1952).

${ }^{18}$ Kaufman v. Shoenberg, -Del. Ch.-, 91 A.2d 786, 792 (1952). 
in whieh the option was held to have been awarded for "proper" consideration there was some element, either in the plan itself,"10 or in the surrounding circumstances, ${ }^{20}$ reasonably calculated to keep the key-executive in the corporation's employ for some duration of time, usually a time reasonably related to the duration of the option. In the cases in which the consideration was held "inadequate," such as Kerbs v. California Eastern Airways, Inc.," there was lacking from the plan such provision which would assure that the key-executive would be retained for some reasonable duration of time.

Advisability of Stockholders' Vote. Self-Dealing. ${ }^{22}$ The closer the identity of the option recipient to the directors, the greater the need for shareholders' approval of the stock option plan because of its vulnerability to the charge of invalidity on the ground of self-dealing. On general principles relating to deals with interested directors, such plans might be invalidated where there is a majority of such interested directors, ${ }^{23}$ or where there is a lack of a disinterested quorum of directors, ${ }^{24}$ or, perhaps by the strict "prophylactic rule," if there are any interested directors. ${ }^{25}$ However, at most the plan is only voidable, although in such cases occasional judicial statements also require fairness in the option. ${ }^{20}$ Should there be any danger of invalidity for self-dealing, the safest course to be pursued would be to obtain shareholders' approval. Illustrative of this is the recent case of Kanfman $v$. Shoenberg. ${ }^{27}$ Not-

${ }^{10}$ See the $M C Q u i l l c n, W y l e s$, and Abrams cases supra note 16.

${ }^{20}$ See the Sandler and Wise cases supra note 16.

${ }^{21}$ See note 17, supra. Cf. Holthusen v. Edward G. Budd Mfg. Co., supra note 16.

${ }^{22}$ See generally WashinatoN AND Rothchid, op. cit. supra note 7, pp. 249 et seq.; anno. 175 A.L.R. 577 and 72 A.L.R. 238.

${ }^{23}$ Re MeCarthy Portable Elevator Co., 196 Fed. 247 (N.J. 1912), aff'd 201 Fed. 923 (3rd Cir. 1913); Karns v. Industrial Comm., 50 Ariz. 466, 73 P.2d 104 (1937); Oil Fields Corp. v. Hess, 186 Ark. 241, 53 S.W.2d 444 (1932).

${ }_{24}$ Rugger v. Mt. Hood Electric Co., 143 Ore. 193, 20 P.2d 412 (1933), rehearing denied 143 Ore. 225, 21 P.2d 1100 (1933); Burton v. Lithic Mfg. Co., 73 Ore. 605, 144 Pac. 1149 (1914).

26 Monterey Water Co. v. Voorhees, 45 Ariz. 338, 43 P.2d 196 (1935); Interstate Investment \& Development Co. v. Webster, 188 Iowa 1389, 177 N.W. 554 (1920).

${ }^{28}$ Kerbs v. California Eastern Airways, supra note 17; Blish v. Thompson Automatic Arms Corp., 30 Del. Ch. 538, 64 A.2d 581 (1948); Keenan v. Eshleman, 23 Del. Ch. 234, 2 A.2d 904 (1938). Cf. Gottlieb v. Heyden Chomical Corp., -Del.-, 90 A.2d 660 (1952), roversing -Del. Ch.-, 83 A.2d 595 (1951), reargument granted -Del.-, 91 A.2d 57 (1952).

27 See supra note 18 . 
withstanding the unique provision in the defendant C. I. T. Finance Corporation's certificate of incorporation which provided for the counting of interested directors for quorum purposes, the court noted that, ". . . our Supreme Court, in considering a stoek option plan approved by a board which had to count interested directors in order to make a quorum, concluded that such action could be effectively ratified by the stockholders [citing Kerbs $v$. California Eastern Airways].' Wh While the court in the Kerbs case stated that the directors action was "voidable only and thus subject to ratification by stockholders," 29 the same court on the same day, in Gottlieb v. Heyden Chemical Corp., ${ }^{30}$ held that ratification can never constitute the only requisite to validity, unless such ratification is unanimous. "An unconscionable deal between directors personally and the corporation they represent" caunot be validated by majority stockholder approval (italics supplied). ${ }^{31}$

Another problem is presented where the key-executive-optionee owns much of the outstanding stock and therefore would have an adverse interest when voting on the option plan. Here, out of excess caution it may be advisable to obtain the majority vote of the disinterested stockholders to preclude any possible difficulty which may subsequently arise. Where the optionee is a dominating personality, be he a majority stockholder or a dominating director, the courts may be inclined to disregard the regularity of the corporate action and invalidate the option as being self-voted. However, there is authority to uphold the validity of the action where the compensation received by the key-executive is for services apart from his duties as a director. ${ }^{32}$ Notwithstanding this latter decision, it is advisable to get stockholder approval for such plans where there is a dominating individual. An additional reason for getting stockholders' approval for the grant of the option and the issuance of stock under the plan is to avoid the question of whether such action may be taken by the directors alone. ${ }^{33}$ While it is

${ }^{28}$ Supra note 18 at 791. The Kerbs case is eited supra note 17.

${ }^{20}$ Supra note 17, 90 A.2d at 659. Cf. Blish v. Thompson Automatic Arms Corp., 30 Del. Oh. 538, 64 A.2d 581 (1948); Keenan v. Eshleman, 23 Del. Ch. 234, 2 A.2d 904 (1938).

${ }^{30} \rightarrow$ Del.—, 90 A.2d 660 (1952).

a1 $I \bar{d}$. at 663 .

${ }^{32}$ Mrossoth v. Central Bus. Corp., 104 Conn. 683, 134 Atl. 236 (1926); cf. Lofland v. Cahall, 13 Del. Ch. 384, 118 Atl. 1 (1922).

${ }^{33}$ Chicago City Railway Co. v. Allerton, 18 Wall 233, 235, "[A] change so organic and fundamental as that of increasing the capital stock of a corporation beyond the limit fixed by the eharter cannot be made by the directors alone. .. [but]... should regularly be accepted by the stockholders." 
generally believed that directors may issue stock up to the total number of shares authorized by the charter, there is just enough force to the contrary argument to make it advisable to avoid the possibility.

Securities Act of 1933. While this comment does not purport to discuss the effect of the Securities Act of $1933^{34}$ upon stock option plans for key-executives, reference should be made to a vory recent holding which is pertinent at this point. Despite the fact that an offer by a corporation to sell stock to its several hundred shareholders has been held ${ }^{35}$ to be a "public offering" and therefore not within the private offering exemption ${ }^{30}$ of the Act, an offering of stock by a corporation to its key-executives, even if they number several hundred, has been held to be exempt from the registration and prospectus requirements of the Act, being considered a transaction by an issuer not involving a public offering. ${ }^{37}$ Thus, there would be no conflict with the Securities Act where the options are limited to key-executives.

\section{The Problem of Taxation}

The enactment of the Revenue Act of $1950^{38}$ added a new section to the Internal Revenue Code which gave new impetus to the use of stock option plans. In general, Section 130A, the new section, provides that under some conditions the profits of such plan would be taxed as long term capital gains, rather than as ordinary income earned in the period in which the option is exercised. To properly appreciate the ramifications of this new section (as modified by the Revenue Act of 1951) ${ }^{39}$ a brief summation of the law prior to 1950 is presented.

Until February 26, 1945, the profits from stock options would have been taxed in one of two ways: (1) if the transfer of stock

${ }^{34} 15$ U.S.C. $\$ 77 \mathrm{e}$ et seq.

${ }^{36}$ Securities and Ex. Comm. จ. Sunbeam Gold Mine Co., 95 F.2d 609 (9th Cir. 1938).

${ }^{36} 15$ U.S.C. $\$ 77 \mathrm{~d}(1)$.

${ }^{37}$ Securities and Ex. Comm. v. Ralston Purina Co., -F.2d- (8th Cir. Nov. 21,1952 ), reported in brief in 21 U. S. Law Week 2259 (Dec. 2, 1952), "There are obvious distinctions between an offering of securities to all of the stockholders ... and an offering, without solicitation, of common stock to a solocted group of key employees of the issuer ... with the sole purpose of enabling them to secure proprietary interests in the company or to increase the intorest already held by them."

${ }^{38} 26$ U.S.C. $\$ 130 \mathrm{~A}$.

${ }^{30} I d$. $130 \mathrm{~A}(5)$. 
to the executive was found to be for the purpose of an investment by the executive in the corporation, the transaction was not subject to tax until the stock was sold, and then only at the capital gains rates; $;^{40}$ or (2) if the transfer was to be as a reward for services rendered or to be rendered, the difference between the market price and the price paid by the employee was held to be taxable as ordinary income at the time the option was exercised. ${ }^{41}$

However, the Supreme Court of the United States, in Commissioner $v$. Smith, ${ }^{42}$ the first case coming before it on the question of executive stock options, rendered a decision which brought about a change in the tax rules stated above. The Smith case held that only where an option is concededly granted an employee as compensation for his services and the option has no value at the time, the difference between the market value of the stock and the price paid upon exercising the option will be regarded as ordinary income at the time the option is exercised and the stock is received. This decision in itself did not transform the law, but was the reiteration of the rules as stated above, applied to a particular case. The court said: "Section 22(a) of the Revenue Act is broad enough to include in taxable income any economic or financial benefit conferred on the employee as compensation, whatever the form or mode by which it is effected." 43

After the decision in the Smith case, the Treasury Department issued T. D. 550744 and I. T. 3795,45 which removed the capital gains features of the regulations that existed prior to the Smith case, and the new regulations state, in effect that an employee exercising an option to purchase stock from his employer-corporation receives taxable income at the time the option is exercised to the extent of the difference between the market value of the stock at the time of exercise and the option price. Thus, under these regulations, the distinction between stock issued as additional compensation and stock purchased as an investment was eliminated. This was the status of the law from February 26, 1945, the date to which

¿o Bothwell v. Commissioner, 27 B.T.A. 1351 (1933), aff'd 77 F.2d 35 (10th Cir. 1935); Delbert B. Geeseman, 38 B.T.A. 258 (1938).

11 Albert Russell Erskine, 26 B.T.A. 147 (1932); Edward J. Epsen, 44 B.T.A. 332 (1940); Estate of Edward J. Connelly, 45 B.T.A. 374 (1943), aff'd 135 F.2d 64 (6th Cir. 1943).

2324 U. S. 177 (1945).

s. $I d$. at 181.

4 1946-1 Cuar. Butr. 18.

19 1946-1 Cưr. BULr. 15. 
the regulations were made retroactive, to December 31,1949 , the date to which Section 130A of the Internal Revenue Code was made retroactive.

The Senate Finance Committee Report on the Revenue Act of 1950 noted the evil ${ }^{46}$ which it wanted to correct by stating:

"Since the employee does not realize cash income at the time the option is exercised, the imposition of a tax at that time often works a real hardship. An immediate sale of a portion of the stock acquired under the option may be necessary in order to finance the payment of the tax. This, of course, reduces the effectiveness of the option as an incentive device." 47

The pertinent provisions of Section $130 \mathrm{~A}$ provide that, if, at the time the option is granted, it is restricted the employee does not realize any income when the option is received or exercised, but any taxable gain is postponed until the stock is sold at a gain, which is treated as a capital gain rather than ordinary income. A restricted option plan must satisfy all of the following requirements before it will be classed as restricted:

(a) At the time the option is granted, the option price is at least $85 \%$ of the fair market value of the stock;

(b) the option caunot be transferred except through the laws of inheritance, and the option can be exercised during the employee's lifetime only by the employee;

(c) the employee does not own stock of the employer, a parent or subsidiary corporation (directly or indirectly) with more than $10 \%$ of the voting power of all classes of outstanding stock; and

(d) the employee is an employee of the corporation, or a parent or subsidiary corporation, granting the option. ${ }^{48}$

In addition, the stock acquired under such a plan must be held by the executive for a period of at least two years from the date of the granting of the option and at least six months after the date the option is exercised.

The disposition of the stock by the individual after the expiration of the two year period from option date and six months after

* For a historical review and application of the Act see Lyon, Employeo Stock Options Under the Revenue Act of 1950, 51 Cor. I. REV. 1 (1951); Alexander, Employee Stoct Options and the 1950 Revenue Act, 6 TAX L. REV. 165 (1951); CCH TAX II 53.105; P-H TAX, I 7760; WASHINGTON AND ROTHcHILD, op. cit. supra note 7, pp. 129 et seq.

17 As reported in P-H TAX, I 7760 .

426 U.S.C. $\$ 130 A$ (a). 
the date of exercise (or upon his death while owning the stock within the period) may result in the increment being included in the key-executive's gross income as compensation. If at the time the option is granted the option price is $95 \%$ or higher of the fair market value of the stock, none of the increment upon the stock, between the option price and the price for which the stock is sold, will be taxed as ordinary income.49 However, if the option price is less than $95 \%$, but more than the $85 \%$ minimum, the disposition of the stock will result in the inclusion in gross income of the amount, if any, by which the option price is exceeded by the lesser of (a) the fair market value of the stock at the time of such disposition, or (b) the fair market value of the stock at the time the option is granted..$^{50}$

Thus, the result of Seetion 130A is to provide conditions, which if met, will enable the executive to sell his option-acquired stock without having any increment computed as "income" under the Treasury Regulations. ${ }^{51}$ But, if it comes under the $85 \%$ to $95 \%$ rule, that part of the increment may be computed as income, and then only in the period in which the stock is sold. The reciprocal benefits $^{52}$ under corporate practice manifest themselves: the corporation is benefited as it will require less inducement to procure better executives; the executives attracted to the corporation are more willing to accept such option plans because of tax benefits.

It is to be noted that the executive must not own (directly or indirectly) more than $10 \%$ of the voting stock in the corporation. Section 130A defines such ownership: "For the purpose of this subparagraph ... such individual shall be eonsidered as owning the stock owned, directly or indirectly, by or for his brothers and sisters (whether by the whole or half blood), spouse, aneestors, and lineal descendents ...." Th3 This limitation may hamper option plans in the small, closely held corporation.

Another point to be considered is that, if the option terms are modified, extended, or renewed, the change is considered the granting of a new option. ${ }^{54}$ Accordingly, a "restricted stock op-

1 Id., subsection (b).

- $\mathrm{Tbid}$.

5ee notes 40 and 41 , supra.

"Although the law was publicized as a measure to close "loopholes" in the Revenue Code, members of the tax bar soon after its enactment began to refer to the 1950 Revenue Act as the "loophole closing and opening act." Lyon, op. cit. supra note 46.

c3 26 U.S.C. I30A (d) (C) (i).

* Id., subsection (e) (1). 
tion" may, as a result of such modification, cease to be such; or, by modification, an option plan may become "restricted." Further, if, within the period prescribed, the employee disposes of the stock acquired under the option, the new rules of Section $130 \mathrm{~A}$ making such increment "capital gains" will not apply, and the profit from such disposition will be taxed as ordinary income.

From the point of view of the corporation, no deduction is allowed under Section 23(a) with respect to a transfer of stock under a stock option qualifying under Section 130A. "The tax sacrifice is but an element of compensation and its propriety must be judged in terms of the total compensation paid to the executive and the total cost of such compensation to the corporation.' 950

The problem of taxation of the stock option plans will be further discussed following an analysis of the problem of salary stabilization, so that problems common to both may be considered together.

\section{The Problem of Salary Stabilization}

The Salary Stabilization Board, formed pursuant to authority in the Defense Production Act of 1950, ${ }^{50}$ issued GSSR- $4,{ }^{57}$ the regulation controlling the use and application of stock option plans. Under this regulation stock option plans require the approval of the Office of Salary Stabilization, unless they can meet all the requirements of section 3 of GSSR-4, which, in essence, requires:

(a) The stock option is a "restricted stock option" within the meaning of section $130 \mathrm{~A}$ of the Internal Revenue Code;

(b) at the time the option is granted, the option price is at least $95 \%$ of the fair market value of the stock subject to the option; and

(c) the option is granted as an incentive and to encourage stock ownership by the employee and not to provide an increase in compensation. ${ }^{58}$

Any stock option plan not meeting the requirements of section 3 will have to receive approval from the Office of Salary Stabilization prior to the inauguration of the plan.

${ }^{55}$ WASHINGTON AND ROTECHID, op. cit. supra note 7, p. 167.

56 50 U.S.C. APP. $\$ 2061$ et seq., as amended by PUBLic LuWW 69, 82d Cong. (1951) and Pubur Law 96, 82d. Cong. (1951).

${ }^{5 \tau}$ Issued October 30, 1951, revised April 8, 1952, amended August 13, 1952. See 32A Code FED. REGS. 1723; CCH, EMrERGENOY LABOR, Tा 45,400-45,411; P-H LABOR, กा 18,168-18,168.11.

${ }^{68}$ CCH Eameraency Labor, If 45,403; P-H Labor, If 18,168.3. 
Section 6 of GSSR-4 requires that stock options "authorized by this regulation are authorized only for use as incentives and to encourage stock ownership by the employees in the manner contemplated by Section 130A of the Internal Revenue Code and shall not be used to provide increases in compensation not otherwise authorized ...." W59 While this may appear to be in conflict with the basic requirement laid down by the decisions that option plans are to be awarded for consideration, such as compensation, and not solely for the purpose of giving the key-executive an ownershipinterest in the corporation, what the courts seek in these cases is to ascertain that there was a valid quid pro quo received by the corporation. In preparation of stock options during the life of GSSR-4, care should be taken lest the consideration on the part of the corporation to the executive be construed as "compensation." Perhaps the best way to effect this "non-compensation" stock option plan would be to require some consideration which could not be ehallenged as compeusation, such as the payment of cash by the executive for the option. A better maneuver in the preparation of this option might be to require reciprocal options; the stock option from the corporation to the executive, and an employment option from the executive to the corporation, which latter option would allow the corporation to elect to re-hire the executive at the end of the current employment contract at some rate of compensation provided for in the plan. However, such necesssity will arise ouly where the executive may not desire to take advantage of the tax advantages of Section 130A because of a "leak" in this no-option-for-compensation "dyke," which will allow free flow of such option plans, although it may in reality be given for compensation.

Section 6 of GSSR-4, quoted above for the no-option-for-compensation feature, continues in its last clause to say:

"In the event that the stock acquired upon exercise of a stock option is not transferred, sold, pledged, . . . or otherwise disposed of by the employee for at least two years from the date the stock option was granted and for at least six months after the option was exereised, there shall be a conclusive presumption that the stock option was neither granted nor received to provide an unauthorized increase in compensation." 60 (Italics supplied.)

It is doubted if, in the light of this clause, any court would cast aside any option which met the conditions expressed in the

${ }^{\circ 0}$ CCH EMERgency LaBor, If 45,406; P-H LABOR, I 18,168.6.

${ }^{\circ 0} I d$. 
above clause. Thus, if the executive is willing to accept the de ferred compensation in place of present compensation, it probably would not be termed a violation of the Defense Production Act. Further, if the option is designed to be qualified as a "restricted option plan" under Section 130A of the Internal Revenue Code (which would be required if no approval were to be sought for the plan) the key-executive would be compelled to so hold the stock anyway. So, the key-executive would be shooting two birds (GSSR-4 and Section 130A) with one shot.

In addition there is a provision in GSSR-4 under which it would be possible to grant an option for compensation. Section 4 of the regulation provides that an option may be granted for compensation if:

"... at the time the option is granted, the employee is entitled to receive a 'chargeable increase in compensation' in an amount at least equal to the difference between 95 percent of the fair market value at such time of the stock subject to the option and the option price of such stock. . . "

This "chargeable increase in compensation" is interpreted to mean "an increase in salary or other compensation that may properly be granted an employee under the salary stabilization regulations or orders." S2 So, where an increase in compensation is allowed by the Salary Stabilization Board, it may be given in the form of a stock option. Further, the Board is authorized to approve "employee stock plans where the employer has had a prior practice of raising capital through such plans." ${ }^{\prime 63}$ All other stock option plans must first receive the prior approval of the Board before it can be granted. Because of the necessity for the filing of applications and reports and the omnipresent possibility of rejection of the plan, it would be best to prepare the option plan so that it will be within the requirements of "qualified" option plans.

\section{Conclusion}

We must recognize the facts of present day corporate life and that those facts are inextricably bound up with the federal tax laws and the salary stabilization regulations. As both GSSR-4 and Section $130 \mathrm{~A}$ each modify the law as it cxisted prior to their enact-

a1 CCH EArbrgency Labor, If 45,404; P-H Labor, If 18,168.4.

$02 I d$.

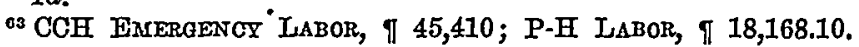


ment, so, too, do they modify each other. While Section $130 \mathrm{~A}$ permits an option to be granted at $85 \%$ of the fair market price, it recognized that only those at $95 \%$ or higher will be free from income taxation, if the requirements are met. In consonance, GSSR-4 allows the stock option to be granted where the price is also $95 \%$ or more of the fair market price. But GSSR-4 will make fewer the number of option plans which will be granted at less than $95 \%$ because of the requirement that they cannot be granted below that percentage unless compensation is permitted.

Both GSSR-4 and Section 130A raise the questions: What is market price? How will this be determined where there is no market for the stock at the time the option is granted or where the corporation is a small, closely held one where the stock is not often sold? What about the situation where there is a market for the stock, but it is so unsettled that it would be difficult to place any particular price on the stock?64 A possible solution to these questions might be to (1) get a fair appraisal of the stock; (2) restrict the sale of the stock for several years after exercise, requiring resale to the corporation at a set price; and (3) recite that the option is not for compensation but to allow the executive to obtain an ownership-interest in the corporation. ${ }^{65} \mathrm{By}$ this means, the corporation would probably be protected if there is any question subsequently about the fairness of the option price, or whether it actually comes above the $95 \%$ or $85 \%$ level. This problem of selecting a fair market price is further complicated by the Treasury's refusal to issue a ruling approving a contemplated valuation in such a situation. ${ }^{66}$

While under Section 130A of the I. R. C. it is possible to pledge the stock within the limits of "two years after granting of the option and six months of exercise of the option," doing this would be in violation of GSSR-4. So, where the executive could pledge

\footnotetext{
"As was the situation in the Geeseman case, supra note 40, where the market price was above the option price both at the time the option was granted and at the time it was exercised, but it was fluctuating. Here, it was held that the employee did not receive any taxable income, rather the increment would be taxed as capital gains. But such cases do not help us determine a market price for purposes of knowing if our option is above the $85 \%$ or $95 \%$ level.

${ }^{\text {ot }} C f$. J. K. I IASSER, REPorTS ON TAXES (Not. 15, 1952).

o MERTENs, IAW of General Incoste TaxamoN (Supp. 1952), \& 5.25, note 15a. Since the salary stabilization regulation relies so heavily upon the tax law, action by the Treasury Department would probably influence the Salary Stabilization Board to the same extent.
} 
the stock for future sale and still get the benefits of the Revenue Code, he cannot do so while GSSR-4 remains in effect.

The situations covered by these problems concern options granted by the corporation itself and do not cover situations where the option is granted by someone else, such as principal stockholder ${ }^{67}$ of the employer corporation. Presumably, in such situations the options will not fall within the terms of Section 130A for tax purposes, nor GSSR-4 for stabilization purposes.

${ }^{67}$ As was the situation in C. A. Van Dusen, 8 T.C. 388 (1947), aff'd 166 F.2d 647 (9th Gir. 1948). 